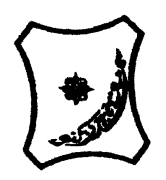

Bayero Journal of Pure and Applied Sciences, 8(2): 220 - 224

Received: June, 2015

Accepted: December, 2015

ISSN $2006-6996$

\title{
THE IMPLICATIONS OF AGRO-CHEMICAL COMPOUNDS (FERTILIZERS, PESTICIDES AND HERBICIDES) ON FARMING/AQUACULTURE ACTIVITIES IN THE LAKE-CHAD AND ITS POSSIBLE CURRENT/FUTURE SOCIAL EFFECTS
}

\author{
Aliyu, M., Grema A.M., Muhammed, A.* and Abubakar, S.M.** \\ Crop Production programme, School of Agriculture and Agricultural Technology, Abubakar Tafawa Balewa \\ University, Bauchi, \\ *College of Agriculture and animal science, Division of Agricultural colleges, Ahmadu Bello University, PMB 2134, \\ Mando Road, Kaduna. \\ ** Department of Science Education, Faculty of Technology Education, Abubakar Tafawa Balewa University, Bauchi,
}

\begin{abstract}
Field survey and Laboratory analysis were carried out to determine the implications of agro-chemicals effluent on Lake Chad water. Historically societies used traditional farming methods involving rainfed agriculture and limited ground water withdrawal with irrigation though an ancient practice, it affected only small parts of the world. Water in Lake Chad is facing serious environmental problems from prolong drought to desertification, pollution and biodiversity reduction. The use of water for extensive agriculture by the lakes riparian states is reducing the water and stressing the ecological balance affecting the organisms depending on it and also its availability to its inhabitants. Water quality is also an important issue in the Lake Chad especially where the rainfall being the natural input into the system is small, greater risk of fertilizer, pesticides, and other agro-chemicals/inputs, runoff from the soil to the lake water and also salt accumulation threat are imminent. The assessment of the Lake Chad water resource quality was therefore carried out carefully while understanding the linkage and interaction with Agro-chemicals using stratified random sampling method for data acquisition and assessment on the site. The results of the experiment indicated that five parameters, namely, PH, Cadmium, Iron, Magnesium and chlorine have contaminant levels above the threshold limit as major sources of pollution in the lake with possible existing and future problem. As a result of the adverse effect of the agrochemicals runoff in the Chad water at Kirinowa. It can be concluded from the results of this study that the lake is under pollution of metals from sources of agricultural operations, due to indiscriminate application of pesticides, herbicides and fertilizers.
\end{abstract}

Key words: Lake Chad, Agro-chemicals, Accumulation, Contamination, Pollution.

\section{INTRODUCTION}

Lake Chad being, the $4^{\text {th }}$ largest lake in Africa is a major source of livelihood and economic activity to 37 million people living around the lake. The four riparian countries of Lake Chad are Chad, Nigeria, Niger and Cameroon, with a current water size of $1,350 \mathrm{~km}^{2}$ and drainage basin size of $2,434,000 \mathrm{~km}^{2}$, approximately $60 \%$ of the basins populace depends on agriculture for fishing activities and to cultivate common crops such as cotton, groundnut, sorghum, cassava, millet, rice and onions. The farming systems, as studied in the Chad Basin are to a large extent overlapping and complementary so that there is hardly a complete dependency on one single type of land use (farming). The four main (4) farming system in the drainage basin are the ordinary village farming (rainy season farming), cash crop farming (irrigation), dry season cultivation (receding lake shores) and agro-pastoralism (herds/cattle rearers) (Braukämper et al 1993).

As most farming activities in the drainage basin are either rain fed or irrigated, the high dependence on its resources is leading to dramatic shrinking of the lake, poor irrigation practices, chemical fertilizer misuse further aggravated loss of soil fertility in the basin which in turn is affecting the lake's ecosystem (Oguntola et al 2006). UNESCO, (2008),reported that the combined effect of climate fluctuation and unsustainable water projects for agriculture in Lake Chad such as the South Chad Irrigation Project in Nigeria and Mamdi Polder Project in Chad are greatly reducing the river flow into the lake. This has also led to the reduction of annual flood plains, loss of canopy cover, and increased in resource dependence which is leading to poor irrigation practices, chemical fertilizer misuse and aggravated loss of soil fertility in the basin. Kirinowa is a town located in Marte Local Government in Borno State, Nigeria between latitude $12^{\circ} 26^{\prime}$ North and longitude $13^{\circ} 56^{\prime}$ East. Most of its populace being peasant farmers and the host to state owned Chad Basin Development Authority (CBDA) which introduced an irrigation scheme in the 1970s where the locals provide labour and the scheme provides water (irrigation), mechanized services and fertilizers (Braukämper, et al 1993).

According to LakeNet, (2008) the lakes fisheries have suffered from a combination of upstream damming, drought, over fishing, and increased juvenile catch due to the use of smaller mesh nets. 
Over 370 species of birds have been inventoried in the lake basin. Nesting habitat for the black-crowned crane has been significantly diminished. Animals in the basin include oryx, gazelles, elephants, black rhinoceros, and the Lake Lere manatee. Water dependent species include crocodile, hippopotamus, waterbuck and situanga.

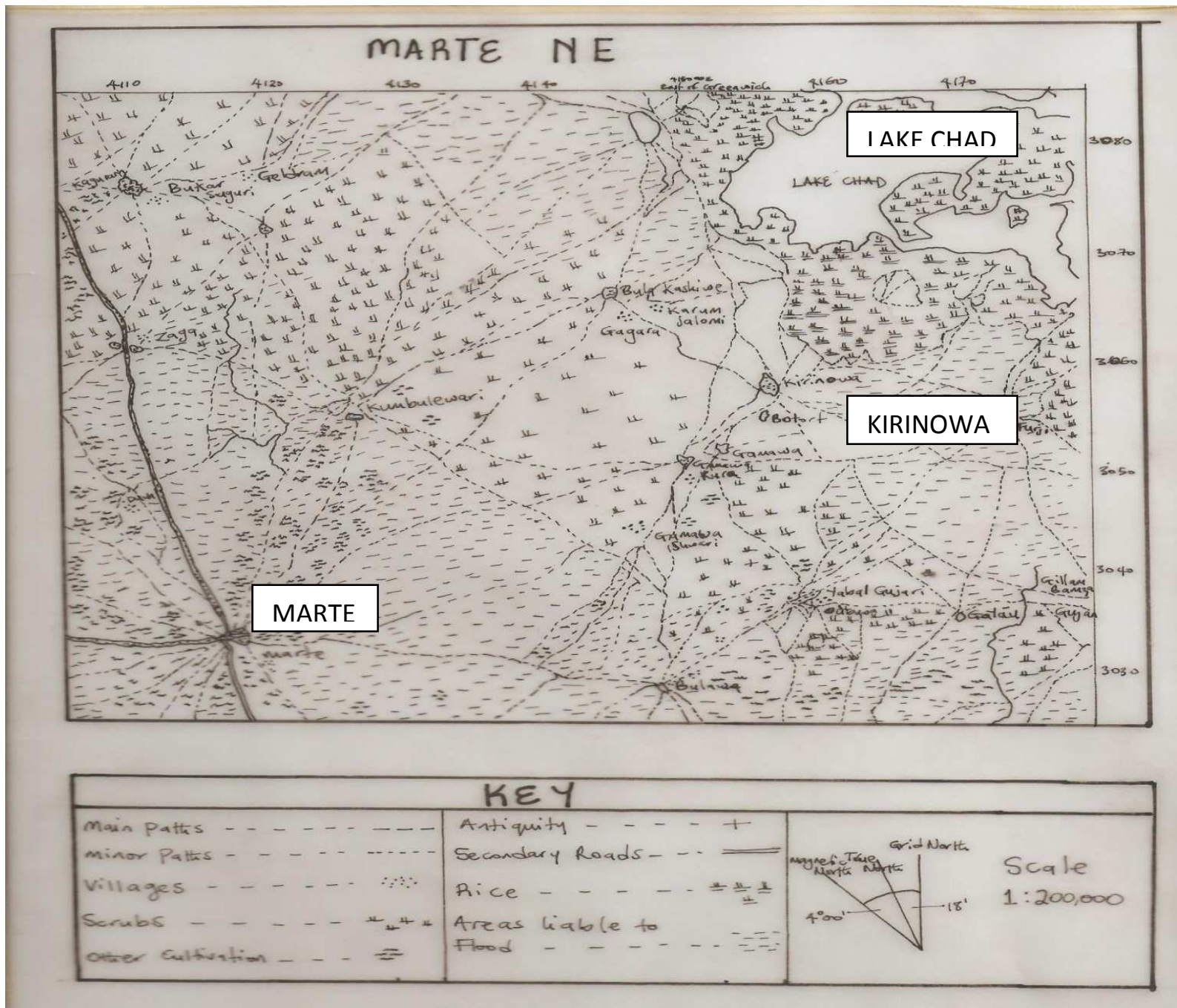

Fig1: Topographical map of Kirinowa Town, Marte Local Government Area

Source: Borno State Ministry of Land and Survey, BSMLS (1985)

DTCA in February 2007, in its communiqué on the regional roundtable on sustainable development of the Lake Chad Basin stressed the need to assess the impact of the use of fertilizers and agro-chemicals on the quality of the Lake Chad water. This therefore provides the basis for this research, which in the long run will enhance the understanding of the current situation of the lake and in ensuring its sustainability.

The aims of this experiment was therefore with the specific objective to determine the concentrations of agro-chemical compounds such as total alkalinity, nitrates, sulphates, heavy metals etc and also to evaluate the implications of agro-chemicals such as Pesticides, fertilizers, and Herbicides.

\section{MATERIALS AND METHODS}

\section{Study Area}

The study area is the Lake Chad Basin which is in Nigeria, Chad, Niger Republic and Cameroon. The area extends between latitudes $11^{\circ} 00^{\prime}-14^{\circ} 00^{\prime} \mathrm{N}$ and longitudes $11^{\circ} 00^{\prime}-14^{\circ} 00^{\prime} \mathrm{E}$. The Chad Basin is the largest inland drainage system in Africa with an area of about $1,536,000 \mathrm{~km}^{2}$ in which the Lake Chad is situated. Lake Chad is a hydrographic closed drainage basin (endoheic basin) with a current water size of $1,350 \mathrm{~km}^{2}$, which is less than $10 \%$ of the lake's actual size as of 1962 .

The study area Kirinowa is located in Marte Local Government, Borno State situated on latitude $12^{\circ} 30^{\prime} \mathrm{N}$ and longitude $13^{\circ} 41^{\prime} \mathrm{E}$ as stated in Fig 4 BSMLS topographical map below. A sudano sahelian climate zone, with an annual average rainfall of $320 \mathrm{~mm}$ with semi arid vegetation located on the banks of Lake Chad. Majority of inhabitants in Kirinowa town are Shuwa Arabs followed by the Kanuri tribe and both depends on agricultural activity as a source of their livelihood (Radojevic and Bashkin 1999). 
Bajopas Volume 8 Number 2 December, 2015 Kirinowa canal, Lake Chad

The Kirinowa adduction canal dredged by Chad Basin Development Authority (CBDA) to feed the Kirinowa pump station is to irrigate vast flood plains in the basin. The pump station, dikes and other diverse infrastructures constructed are being used by CBDA under its South Chad Irrigation Project (SCIP) in the basin's flood plains in Kirinowa and surrounding areas such as Njine, Bulau, Kamzamo and Lari for extensive irrigation farming. The adduction canal has an average depth of $10 \mathrm{~m}$ and an average width of $200 \mathrm{~m}$. The major source of livelihood for the indigenes is farming which makes the lake water to be vital for their sustainability Akan et. a/(2012)

\section{Study Design}

This research encompasses the impact of agrochemicals on the water quality of the Kirinowa canal/area. Kirinowa harbours one of Nigeria's largest agricultural river basin development areas where extensive irrigation and rain fed agriculture takes place with massive application of fertilizers and pesticides going on. This study intends to examine the effect on the water quality of the Lake Chad Kirinowa area and to assess the possible negative impacts as a result of the agro-chemical run-off into the water body (Ademoroti, 1996)

\section{Description of Sampling Site}

Five representative sampling sites were chosen at different points of the Kirinowa canal. All the sampling points were of at kilometer distance range away from each other mid canal area at every sampling point. The first three (3) samples were taken at one kilometer interval while the last two samples were taken at two kilometer interval making the whole research area to be seven (7) kilometer within range of the canal.

\section{Sampling method}

Stratified random sampling method (Evans et al 1957) was used to take lake water samples at five (5) different sampling points from the Lake Chad canal where agricultural activities takes place within the radius of $300 \mathrm{~m}$ maximum from adjacent agricultural site. There was a minimum of $1 \mathrm{~km}$ from one sampling point to the next. Water samples were collected in $2 \mathrm{dm}^{3}$ bottles ( 2 litres) and taken to the laboratory for analysis (Anon,1992).

\section{Laboratory Procedures}

Water samples taken from the canal lake water at 5 different sites were tested in the laboratory to assess the presence of certain agro-chemicals and their concentration levels in the water. The thirteen agrochemicals analyzed were the major active ingredients of several agricultural fertilizers, pesticides and additives widely used in the research study site, which will be discussed below in summary of the chemicals test and concentration found.

Samples for analysis of metals ( $\mathrm{Pb}, \mathrm{Cu}$ and $\mathrm{Cd}$ ) were preserved with $3 \mathrm{ml}$ concentrated $\mathrm{HNO}_{3}$ per litre in the field. Sulphates and nitrates were collected in $2 \mathrm{dm}^{3}$ plastic bottles. All samples were refrigerated and analyzed for 24 hours. All plastics and glass wares were pre-washed with detergent water solution and soaked for 48hours in $50 \% \quad \mathrm{HNO}_{3}$ and rinsed thoroughly with distilled deionised water and air dried in a dust free environment (Adekunle et al., 2007).

\section{Key Informant Interviews}

For the purpose of this research, key informant interviews were conducted in Kirinowa town's medical/farmer union personnel, Chad Basin Development Authority Maiduguri staff and Lake Chad Research Institute Maiduguri staff to obtain sets of responses. Most of the informations obtained were based on the past and current land tenure system, irrigation patterns, crops cultivated and agro-chemicals used (WHO, 2002).

\section{Direct Observation}

Personal observation was done while seeing and taking photographs of algal bloom, water clarity, living organism in and around the lake water and crops cultivated around the area. Other observed information is topography, vegetation, terrain, settlement pattern, development and infrastructures at the research area.

\section{Data Statistical Analysis}

The analytical tools used were the Simple descriptive statistics, Confidence interval and T-test.

\section{Results and discussions}

The results of the water quality measurements are summarized in (Tables 1, 2, 3 and 4) as the parameters were compared with the Standard organization of Nigeria maximum permitted limit. Cadmium, iron, $\mathrm{pH}$, magnesium and chlorine showed significant spatial variations. Total alkalinity and total dissolved solid were in concentration level averagely close to the threshold limit while sulphates, nitrates, calcium, copper, and zinc were significantly lower than its maximum permitted limit in all the five sampling site.

The laboratory analysis result of the thirteen parameters analyzed above clearly shows excess levels of only five chemicals exceeding the maximum concentration limit (MCL) which are shown in the tables.

The results of this study indicated that the lake is under pollution of metals from sources of agricultural operations, due to indiscriminate fertilizer and pesticide waste runoff and other human activities occurring in the area of study where extensive irrigation projects have been taking place for close to three decades. This research draws direct link between the application of agrochemicals by the massive agricultural irrigation project in the area, the water contamination and the environmental problems (secondary impacts) in the lake as a result of the contamination (Anon 2009a, b and c). Large expanse of land being cultivated and irrigated with subsequent continuous use of unsustainable pest and fertility management technique for over three decade led to reduction of water quality (Fada, 1990). This was established from the key informant interviews conducted. The high metal levels of iron, cadmium and magnesium in the lake water at Kirinowa are above significant limit and this strongly indicates that the existing and future reduction in fish production yield is obvious. The high $\mathrm{pH}$ level in the canal bank in the $1 \mathrm{~km}$ sample A station, 3rd and 5th kilometer sample station $C$ and $D$ respectively proves the high algal bloom /eutrophicationoccurring visibly in the lake water, 
thereby showing upcoming possible increase in eutrophication levels. All five sampling stations prove soaring magnesium concentrations signifying the high susceptibility of other toxic soluble pollutants to easily contaminate the lakewater, as magnesium have indirect toxicity effect of increasing solubility. The chlorine levels at all stations were considerably above threshold limit of $0.25 \mathrm{ppm}$ as the minimum and maximum range of chlorine concentration of 14 to $18 \mathrm{ppm}$ in the canal. The high pesticide usage especially 2,4D a chlorophenoxy family is clearly linked to the high chlorine contamination, prevailing respiratory diseases and low aquatic productivity level in recent years. The contamination of the lake water and continued water usage for irrigation, domestic rural communities and by pastoral grazing animals results to health hazards leading to a sharp decline in crop productivity and reduction of trees, shrubs and grasses biomass (Anon 2008a, b and c).

Table 1: Analyzed Lake Water physical properties

\begin{tabular}{llllllll}
\hline Parameters & \multicolumn{9}{c}{ Sample stations (km) } & \multicolumn{2}{c}{ Standards } \\
\hline & A & B & C & D & E & SON* & WHO* \\
pH & 8.76 & 8.84 & 9.14 & 9.14 & 8.85 & $6.5-8.5$ & $6.5-8.5$ \\
TA (ppm) & 125 & 138 & 178 & 178 & 139 & 500 & 200 \\
TDS (ppm) & 305 & 310 & 380 & 386 & 340 & 500 & 500 \\
TA = Total alkalinity & TDS = Total dissolved solid, SON = Standard organization of Nigeria, WHO = World health \\
Organization
\end{tabular}

Table 2: Analyzed Lake Water non-metal properties

\begin{tabular}{llllcccl}
\hline Parameters & \multicolumn{9}{c}{ Sample stations $(\mathbf{k m})$} & \multicolumn{2}{c}{ Standards } \\
\hline & $\mathrm{A}(1)$ & $\mathrm{B}(2)$ & $\mathrm{C}(3)$ & $\mathrm{D}(4)$ & $\mathrm{E}(5)$ & SON* & WHO* \\
Sulphates (ppm) & 5 & 6 & 6 & 4 & 6 & 100 & 500 \\
Nitrates (ppm) & 0.4681 & 0.4532 & 0.3921 & 0.3892 & 0.4521 & 50 & 50 \\
Calcium (ppm) & 4.0485 & 4.9825 & 4.9940 & 4.1001 & 4.1100 & 150 & 75 \\
Chlorine (ppm) & 16 & 18 & 14 & 16 & 16 & 0.25 & 5 \\
\hline
\end{tabular}

Source: Field survey (2008).

SON $=$ Standard organization of Nigeria, $\mathrm{WHO}=$ World health organization

Table 3: Analyzed Lake Water metal properties

\begin{tabular}{lccccccc}
\hline Parameters & \multicolumn{9}{c}{ Sample stations (km) } & \multicolumn{2}{c}{ Standards } \\
\hline & $\mathrm{A}(1)$ & $\mathrm{B}(2)$ & $\mathrm{C}(3)$ & $\mathrm{D}(4)$ & $\mathrm{E}(5)$ & \multicolumn{2}{c}{ SON* WHO* } \\
Copper (ppm) & 0.0162 & 0.0180 & 0.0166 & 0.0146 & 0.0152 & 1.0 & 1.0 \\
Cadmium (ppm) & 0.0014 & 0.0114 & 0.0082 & 0.0186 & 0.0090 & 0.003 & 0.003 \\
Iron (ppm & 1.0084 & 1.1042 & 1.2004 & 1.100 & 1.2010 & 0.3 & 0.1 \\
Zinc (ppm) & 0.0231 & 0.0230 & 0.0300 & 0.0345 & 0.0189 & 3.0 & 3.0 \\
Magnesium $(p p m)$ & 2.9662 & 2.6584 & 2.8254 & 2.8448 & 2.8600 & 0.20 & $\mathrm{NA}$ \\
\hline
\end{tabular}

$\mathrm{WHO}=$ World Health Organization, $\mathrm{SON}=$ Standard Organization of Nigeria, NA=Not available

Table 4: Analyzed Lake Water parameters exceeding maximum concentration limit

\begin{tabular}{lcccccc}
\hline Parameters & \multicolumn{7}{c}{ Sample station (km) } & Standards \\
\hline & $\mathrm{A}(1)$ & $\mathrm{B}(2)$ & $\mathrm{C}(3)$ & $\mathrm{D}(5)$ & $\mathrm{E}(7)$ & SON* \\
$\mathrm{pH}$ & 8.76 & 8.84 & 9.14 & 9.14 & 8.85 & $6.5-8.5$ \\
Cadmium(ppm) & 0.0014 & 0.0114 & 0.0082 & 0.0186 & 0.0090 & 0.003 \\
Iron(ppm) & 1.0084 & 1.1042 & 1.2004 & 1.100 & 1.2010 & 0.3 \\
Magnesium(ppm) & 2.9662 & 2.6584 & 2.8254 & 2.8448 & 2.8600 & 0.20 \\
Chlorine(ppm) & 16 & 18 & 14 & 1 & 16 & 0.25 \\
\hline
\end{tabular}

SON $=$ Standard organization of Nigeria

\section{CONCLUSION}

It can be concluded that from the twelve parameters analyzed at five sampling stations in the Kirinowa canal, Marte LGA only five parameters namely $\mathrm{pH}$, cadmium, Iron, Magnesium and Chlorine indicate significant variations of contaminant levels above the threshold limit standards used. The remaining parameters are not exceeding the Standard organization of Nigeria (SON) limits, and are therefore at acceptable concentrations. It is thus concluded that the lake water especially in areas were extensive irrigation agriculture occur such as Kirinowa as shown in this research is not suitable for direct human and animals consumption. 


\section{REFERENCES}

Adekunle, M., Adetunji, M.T., Gbadebo, A.M. and Banjoko, O.B. (2007). Assessment of Ground Water Quality in a Typical Rural Settlement in Southwest Nigeria. International Journal of Environmental Research and Public Health, (5) 308-309.

Ademoroti, C.M.A. (1999). Standard Method for water and Effluents Analysis," Foludex Press Ltd., Ibadan, : 22-23.

Akan, J. Abbagambo, M. Chellube, Z. and Abdulrahman, F. (2012). Assessment of Pollutants in Water and Sediment Samples in Lake Chad, Baga, North Eastern Nigeria," Journal of Environmental Protection, $\mathbf{3}$ (11):1428-1441. doi: 10.4236/jep.2012.311161.

Anon, R. (1992). Standard Methods of Water and Wastewater Examination," 18th Edition, American Public Health Association, Washintong DC:172pp.

Braukämper, U., Kirscht H., Platte, E. and Thiemeyer, H. (1993). Systems of Land Use in the Firgi Plains of the Chad Basin. Frankfurt a. M., 43-50.

Directorate of Technical Cooperation in Africa (DTCA) (2007). Communiqué on the $1^{\text {st }}$ Regional Roundtable on Sustainable Development of the Lake Chad Basin. SDI-Africa, Vol. 6, No. 4.

Encarta Encyclopedia Student Edition 2008-Current Environmental Problems of Lakes/Lake Chad.

Evans, R.A and Love R.M (1957). The Step Print Method of sampling. A Practical Tool in Range Research. J. Range Manege, Vol. 10: 208-210

Fada, B. (1990). Wheat in Nigeria; Wheat Production in Borno State. LCRI, IAR and UNIMAID, 2123.

Oguntola, J.A., Oyebande L. and Eric, O.O. (2006). Lake Chad; Experience and Lessons Learned Brief. World Bank, 75-92.

WHO, (2002). World Health Organization Standard for Drinking Water," Guidelines for Drinking Water Quality, Vol. 1, Recommendation, France, $181 \mathrm{pp}$.

www.fishdoc.co.uk: Fish Health and $\mathrm{pH}$.

www.kywater.org/ww/ramp/rmtests; $\mathrm{pH}$ and Water Quality.

www.lenntech.com/periodic-chart.

www.unesco.org/UNESCO water portal newsletter No. 178: The Lake Chad Basin.

www.lakeNet.org/Lake Chad.

www.lamotte.com.

www.library.thinkquest.org/the land/lake chad. 